\title{
Small Nuclear Ribonucleoprotein F
}

National Cancer Institute

\section{Source}

National Cancer Institute. Small Nuclear Ribonucleoprotein F. NCI Thesaurus. Code C30091.

Small nuclear ribonucleoprotein $\mathrm{F}(86 \mathrm{aa}, \sim 10 \mathrm{kDa}$ ) is encoded by the human SNRPF gene.

This protein is involved in pre-mRNA splicing. 